YOUNG AMERICAN

MUSLIMS 



\title{
YOUNG AMERICAN MUSLIMS
}

\section{DYNAMICS OF IDENTITY}

\author{
NAHID AFROSE KABIR
}


(C) Nahid Afrose Kabir, 2013

Edinburgh University Press Ltd

22 George Square, Edinburgh EH8 9LF

www.euppublishing.com

Typeset in 10/12.5 Sabon by

Servis Filmsetting Ltd, Stockport, Cheshire, and

printed and bound in Great Britain by

CPI Group (UK) Ltd, Croydon CR0 4YY

A CIP record for this book is available from the British Library

ISBN 9780748669936 (hardback)

ISBN 9780748669943 (webready PDF)

ISBN 9780748669967 (epub)

ISBN 9780748669950 (Amazon ebook)

The right of Nahid Afrose Kabir to be identified as author of this work has been asserted in accordance with the Copyright, Designs and Patents Act 1988 . 